OPEN ACCESS

Edited by:

Hao Sun,

University of California, San Diego,

United States

Reviewed by:

Juan D. Cañete,

Hospital Clínic de Barcelona, Spain

Gerard M. Moloney,

University College Cork, Ireland

Elena Zenaro,

University of Verona, Italy

John MacSharry

University College Cork, Ireland

${ }^{*}$ Correspondence:

Helen M. McGettrick

h.m.mcgettrick@bham.ac.uk

${ }^{\dagger}$ These authors have contributed equally to this work

Specialty section:

This article was submitted to

Cell Adhesion and Migration,

a section of the journal

Frontiers in Cell and Developmental

Biology

Received: 29 November 2020

Accepted: 11 February 2021

Published: 09 March 2021

Citation:

Manning JE, Lewis JW, Marsh L-J and McGettrick HM (2021) Insights Into Leukocyte Trafficking

in Inflammatory Arthritis - Imaging

the Joint.

Front. Cell Dev. Biol. 9:635102. doi: 10.3389/fcell.2021.635102

\section{Insights Into Leukocyte Trafficking in Inflammatory Arthritis - Imaging the Joint}

\author{
Julia E. Manning ${ }^{\dagger}$, Jonathan W. Lewis', Lucy-Jayne Marsh and Helen M. McGettrick* \\ Rheumatology Research Group, Institute of Inflammation and Ageing, University of Birmingham, Birmingham, \\ United Kingdom
}

The inappropriate accumulation and activation of leukocytes is a shared pathological feature of immune-mediated inflammatory diseases (IMIDs), such as rheumatoid arthritis (RA) and psoriatic arthritis (PsA). Cellular accumulation is therefore an attractive target for therapeutic intervention. However, attempts to modulate leukocyte entry and exit from the joint have proven unsuccessful to date, indicating that gaps in our knowledge remain. Technological advancements are now allowing real-time tracking of leukocyte movement through arthritic joints or in vitro joint constructs. Coupling this technology with improvements in analyzing the cellular composition, location and interactions of leukocytes with neighboring cells has increased our understanding of the temporal dynamics and molecular mechanisms underpinning pathological accumulation of leukocytes in arthritic joints. In this review, we explore our current understanding of the mechanisms leading to inappropriate leukocyte trafficking in inflammatory arthritis, and how these evolve with disease progression. Moreover, we highlight the advances in imaging of human and murine joints, along with multi-cellular ex vivo joint constructs that have led to our current knowledge base.

Keywords: imaging, leukocyte, adhesion, migration, arthritis

\section{OVERVIEW OF THE LEUKOCYTE RECRUITMENT CASCADE}

Over the last 30 years, the general understanding of how leukocytes migrate out of the blood, across the endothelium and through inflamed tissues has been extensively researched providing us with a step by step cascade of events (Figure 1) (Ley et al., 2007; Vestweber, 2015). In line with this, imaging techniques for analyzing the individual steps of the cascade, from leukocyte capture through to migration into the tissue, have improved exponentially giving us much more granularity on the temporal and dynamic kinetics of these events and the key molecules involved. Chronic inflammatory arthritis is characterized by the aberrant accumulation and activation of such leukocytes within the synovial tissue, along with tissue-resident stromal cells (fibroblasts) becoming epigenetically reprogrammed, both of which drive tissue and bone damage leading to pain and immobility in patients with, for example, rheumatoid arthritis (RA) or psoriatic arthritis (PsA). The clinical urgency to identify new drug targets that limit the trafficking of pathogenic leukocytes and promote the entry of regulatory cells into chronically inflamed tissues, such as the joint, are partly responsible for driving forward the imaging techniques necessary to visualize these processes in real-time. Here, we explore our current understanding of the mechanisms leading to inappropriate leukocyte trafficking in inflammatory arthritis, and how these evolve with disease progression. 
We provide a historic overview of the imaging techniques that have led to our current knowledge base - considering our progression from 2-D imaging of tissue sections; through to in vitro adhesion and migration assays on sections, purified proteins or single-cell layers; into the realm of real-time imaging of 3-D multicellular ex vivo joint constructs or whole joints, and beyond. For each technique we will highlight the key kinetics, leukocyte subpopulations and molecules discovered and how these advanced our understanding of process-driven pathology of inflammatory arthritis.

\section{IMAGING SYNOVIAL TISSUE - EARLY INSIGHTS INTO PATHOLOGY}

As early as the 1960's researchers used haematoxylin and eosin (H\&E) to stain tissue sections to visualize tissue architecture (Campbell-Thompson et al., 2012) (Figure 2A) and cellular accumulation in the joints from patients with RA or PsA (Muirden and Senator, 1968; Muirden and Mills, 1971). Timecourse experiments in murine models of inflammatory arthritis revealed the accumulation of leukocytes peaked 1-2 days after onset of adjuvant-induced arthritis (AIA) model (Szántó et al., 2004; Gonçalves et al., 2020), day 10 in the KRN serum transfer induced arthritis (STIA) model (LaBranche et al., 2010); and 21 days after immunization in the collagen-induced arthritis (CIA) model (Knoerzer et al., 1997). Similarly, H\&E revealed a substantial number of leukocytes accumulating in the synovium of patients with early (disease duration less than 1 year) and established RA (1.5-20 years), with the degree of infiltration correlating with disease activity rather than symptom duration (Baeten et al., 2000). For both human and murine studies, H\&E analysis of synovium has highlighted the significant role of tumor necrosis factor- $\alpha$ (TNF $\alpha)$ in driving leukocyte infiltration into the inflamed joint: with $\mathrm{TNF} \alpha$ inhibitors (TNFi) reducing leukocyte numbers in the joint leading to reduced clinical scores, which were not seen in non-responders (Williams et al., 1992; Baeten et al., 2000; Barrera et al., 2001), as well as reducing the expression of chemokines within the synovium (Taylor et al., 2000). Similarly, H\&E revealed a potential therapeutic benefit of inhibiting chemokine interactions in AIA, where shortchain peptides modeled on the chemokine glycosaminoglycan binding domain of CXCL8 (interleukin-8) decreased leukocyte accumulation and the overall inflammatory score in treated joints (McNaughton et al., 2018). Whilst H\&E analysis of tissue sections is an integral outcome measure in almost all studies, it is unable to provide any insight into the specific subsets of leukocytes infiltrating the joint, how these evolve with disease or the mechanisms underpinning their accumulation.

Advances in immunohistochemistry (IHC) and subsequently fluorescence microscopy and in situ hybridization (ISH) have expanded our ability to identify individual leukocyte subsets in synovial tissue sections (Menon et al., 2017; Traylor-Knowles, 2018) (Figures 2B,C), furthering our understanding of the composition of leukocytes within the inflamed joint in the various murine models of inflammatory arthritis and human arthritides. For example, monocytes and CD4 T-cell infiltration peaked
2-3 days following onset of AIA, followed by an influx of CD8 T-cells and B-cells which peaked at day 7 (Verschure et al., 1989). Moreover, monocytes and macrophages were observed in the sublining layer of the AIA joint, whilst $\mathrm{T}$ and B-cells were located in perivascular clusters and some in small isolated groups (Dijkstra et al., 1987). Indeed, elevated numbers of CD3 ${ }^{+}$ T-cells, CD20 ${ }^{+}$B-cells, and $\mathrm{CD} 8^{+}$macrophages, along with a concomitant decrease in the numbers of regulatory T-cells (Tregs) were also observed using IHC in synovial biopsies from RA patients with high disease activity scores compared to patients with lower disease activity or in remission (Zhang et al., 2005; Behrens et al., 2007; Alivernini et al., 2017). Moreover, anti$\mathrm{TNF} \alpha$ therapy reduced the numbers of $\mathrm{CD}^{+}$T-cells, CD22 ${ }^{+}$ $\mathrm{B}$-cells, and $\mathrm{CD}^{+} 8^{+}$macrophages in the joints of patients with RA over a 2 weeks period (Taylor et al., 2000). Indeed, the combination of CD20, CD138 (marking plasma cells), CD3, and CD68 revealed 3 distinct leukocyte profiles (pathotypes) in the synovium of patients with early and established RA based on the absence of leukocytes (pauci-immune), diffuse myeloid infiltrate or the formation of lympho-myeloid aggregates (Humby et al., 2019; Nerviani et al., 2020). Agreeing with earlier studies that described pauci-immune; diffuse and follicular infiltrates (Wagner et al., 1998; Pitzalis et al., 2013). Crucially these different leukocyte synovial pathotypes impact on a patient's response to therapy - where over $80 \%$ of patients with a lymphomyeloid or diffuse myeloid pathotype showed a decrease in their disease activity (DAS28 score) following treatment with the anti-TNF $\alpha$ drug, certolizumab-pegol, whilst less than $30 \%$ of patients with the pauci-immune pathotype responded (Nerviani et al., 2020). Such studies reveal two important insights firstly leukocyte pathotypes highlight the existence of different leukocyte recruitment and retention signatures in subgroups of RA patients. Secondly, although the exact molecular mechanisms for these signatures remain undetermined, $\mathrm{TNF} \alpha$ clearly plays a major role in the two pathotypes where elevated levels of leukocytes are observed.

Early IHC and ISH studies revealed for the first time the expression pattern of adhesion molecules and chemokines within arthritic joints (Johnson et al., 1993; Salmi et al., 1997; Matsui et al., 2001; Wang et al., 2004). Macroscopically, expression of certain adhesion molecules (selectins and VCAM-1) have been reported to be restricted to a subpopulation of synovial vessels in patients with chronic arthritis; whilst others [intracellular adhesion molecules 1 and 2 (ICAM-1 and ICAM-2)] were ubiquitously expressed (Salmi et al., 1997). In contrast, little E-selectin was detected on vessels in PsA (Veale et al., 1993). Synovial blood endothelial cells located near or within tertiary lymphoid structures appear to acquire a high endothelial vessel (HEV)-like phenotype with the expression of peripheral node addressin (PNAd), an adhesion molecule normally restricted to HEV's, observed on synovial endothelial cells in some, but not all, RA and PsA sections analyzed (Salmi et al., 1997; Cañete et al., 2007) - and which may account for the lymphomyeloid/follicular pathotype described (Wagner et al., 1998; Pitzalis et al., 2013). Similarly, rheumatoid synovial endothelium abnormally expresses high levels of the mucosal specific vascular adhesion protein-1 (VAP-1) (Salmi et al., 1997) - indicating that 
the synovial endothelium acquires the capacity to support the trafficking of gut-homing T-cells during RA pathology. Crucially, the activation status of synovial endothelial cells is sensitive to anti-TNFa therapy, with reduced expression of E-selectin (Paleolog et al., 1996; Tak et al., 1996) and vascular cell adhesion protein 1 (VCAM-1) (Tak et al., 1996) reported in the rheumatoid synovium following treatment - almost certainly accounting for the improvement in disease activity seen in patients with leukocyte rich pathotypes (Nerviani et al., 2020).

In 1976 Stamper and Woodruff transformed tissue analysis from spatial 2-D phenotypic studies to 3-D functional assays (Hirata et al., 2004) (Figure 2D), by allowing lymphocytes to adhere to fixed murine lymph node tissue sections before visualizing their interactions using methyl-green-thionin and light microscopy (Stamper and Woodruff, 1976). Subsequently, groups adapted the Stamper-Woodruff (S-W) assay and began assessing the molecular mechanisms supporting leukocyte adhesion to arthritic synovial tissue. For example, significantly more monocytes adhered to RA synovium compared to other tissues analyzed (foreskin, placenta, and inflamed tonsils), and blocking the capture receptors P-selectin and E-selectin reduced this by $>90 \%$ and $20-50 \%$, respectively (Grober et al., 1993). Similarly, HL-60 cell (a neutrophil-like leukaemic cell line) adhesion to frozen sections of RA synovium was significantly reduced following treatment with an anti-E-selectin functionblocking antibody or the TNF $\alpha$ inhibitor certolizumab pegol (Shu et al., 2012). Thus demonstrating a pivotal role $\mathrm{TNF} \alpha, \mathrm{P}$ - and E-selectin in supporting neutrophil and monocyte recruitment to the RA synovium. Furthermore, Salmi et al. (1997) revealed for the first time mucosal lymphocytes bind to VAP-1 expressed by RA synovial vessels, further supporting the concept that gutspecific trafficking address-codes for lymphocytes are hijacked by the rheumatoid joint. Indeed, the mucosal microbiome is now believed to play a crucial role in lymphocyte trafficking outside the inflamed joint, and is highly likely to influence the phenotype of the cells recruited to the joint (reviewed by Buckley and McGettrick, 2018; Manasson et al., 2020; Xu et al., 2020). This functional analysis of tissue sections allowed for the first time mechanistic studies on the proportion of leukocytes binding with or without interventions to be analyzed. Further studies using tissues from other inflammatory arthritides and at different phases of disease are now required to distinct shared and unique features across arthritides, and how these evolve with disease progression.

\section{DISSECTING THE MOLECULAR MECHANISMS SUPPORTING ABERRANT LEUKOCYTE TRAFFICKING - THE CREATION OF IN VITRO JOINT CONSTRUCTS}

The vast majority of our understanding on the dynamics of leukocyte recruitment has been discovered by visualizing cellcell interactions in vitro using assays that incorporate purified proteins or different tissue-resident cells (e.g., blood vascular endothelial cells or fibroblasts) in either 2-D or 3-D formats, and in some cases that also mimic blood flow (Butler et al., 2009; Mcgettrick et al., 2017). These in vitro static or flowbased adhesion/migration assays enable the real-time imaging of leukocyte behavior as they interact with the substrate, including their motility (Figures 2E,F). As such they have been a vital tool in aiding our understanding of the molecular processes governing disease onset and perpetuation in many arthritides, especially when patient cells or pharmacological agents have been assessed.

\section{2-Dimensional Models}

Surprisingly few studies have visualized each step of the adhesion cascade using leukocytes isolated from patients with inflammatory arthritis and models mimicking the joint that incorporate endothelial cells alone or with relevant stromal components (Figures 2E,F). For example, more T-cells adhered and migrated through inflamed endothelium in vitro when they were isolated from RA (Taylor et al., 2000) or PsA (Dunky et al., 1997) patients compared cells from the control group this was thought to be mediated by $\alpha_{\mathrm{L}} \beta_{2}$-integrin. Interestingly, the adhesive capability of T-cells appeared to be unaffected by whether a patient exhibits active or inactive RA, with similar numbers of fluorescently labeled T-cells observed binding to either resting or IL-1 $\beta$ stimulated endothelial cells over a 6h timeframe (Mertens et al., 1994). Similarly, greater numbers of effector memory $\mathrm{CD} 4^{+}$T-cells from RA patients migrated further into collagen gels over $48 \mathrm{~h}$ following in vitro anti-CD $3^{+}$ CD28-induced activation compared to cells isolated from healthy controls (Shen et al., 2017). Combining these data with IHC and metabolite quantification revealed that T-cells from these clinically active RA patients had reduced glycolytic flux that resulted in the overexpression of TSK5, a podosome scaffolding protein found at the leading edge of the cells causing enhanced migratory capacity in vitro (Shen et al., 2017). This was one of the first studies to highlight the importance of disease-induced metabolic changes in leukocytes on their adhesive and migratory potential. Similar observations have been linked to genes associated with increased risk of developing RA - for example, super-resolution studies revealed that the expression of the PTPN22 variant (PTPN22W) increased $\alpha_{\mathrm{L}} \beta_{2}$-integrin clustering in T-cells resulting in them being more sticky (Burn et al., 2016). Genetic risk factors and abnormal cellular metabolism promote the adhesive and migratory properties of T-cells in patients with RA (Weyand et al., 2020), and potentially other inflammatory arthritides by altering the expression levels or cellular localization of $\alpha_{\mathrm{L}} \beta_{2}$-integrin. Whilst directly targeting $\alpha_{\mathrm{L}} \beta_{2}$-integrin is not a viable treatment option [see review on leukocyte adhesion deficiency (Harlan, 1993; Kuijpers et al., 1997)], targeting the processes regulating its expression and distribution may provide alternative treatment options for arthritides.

TNF $\alpha$ signaling, itself, can induce leukocytes to shed $\beta_{2}$ integrins (Gjelstrup et al., 2010), resulting in increased plasma soluble $\beta_{2}$-integrin (sCD18) concentrations that bind to ICAM1 on the endothelium to reduce the availability of this molecule to leukocytes, thus reducing adhesive interactions (Kragstrup et al., 2014). However, this homeostatic regulatory pathway is 


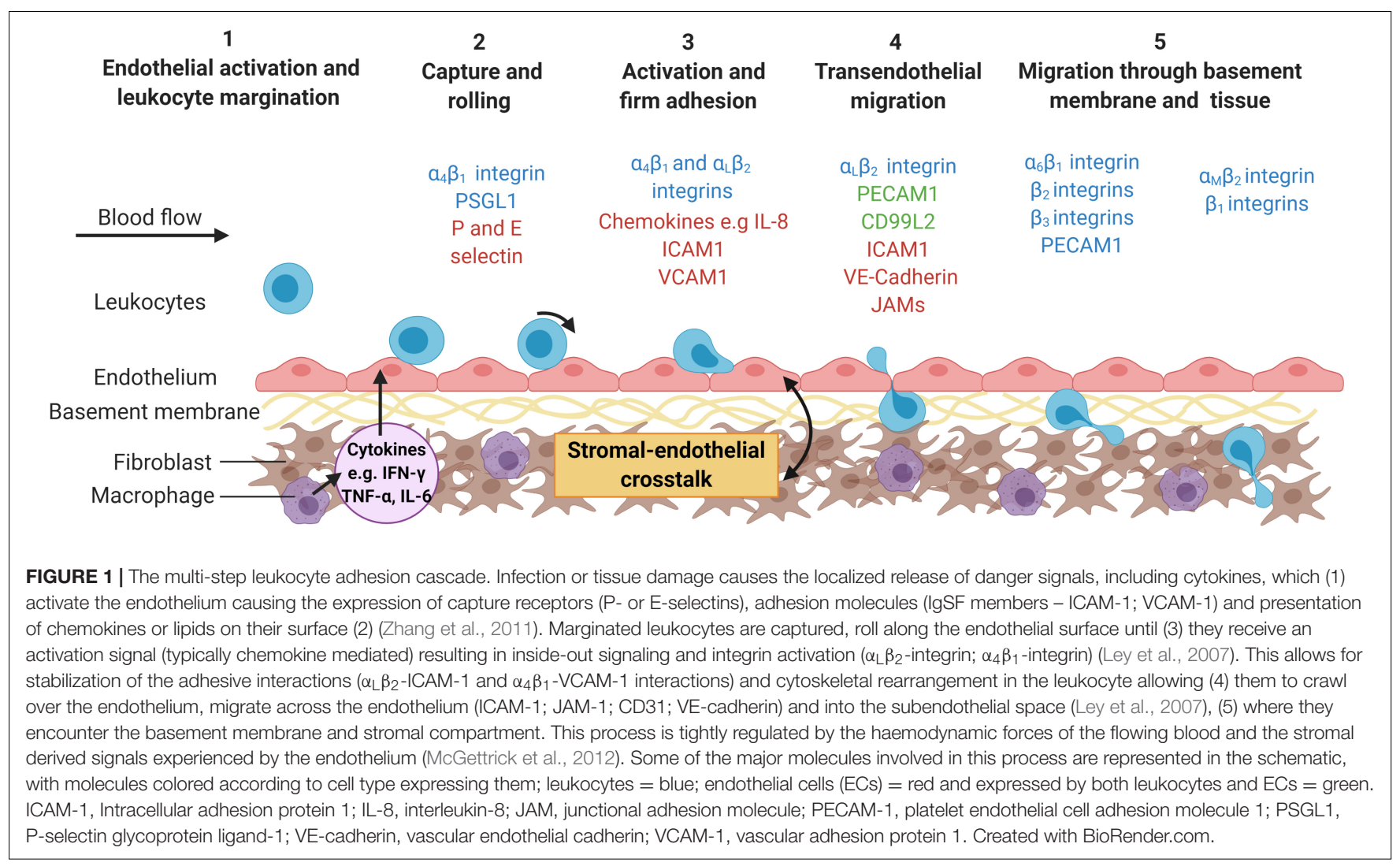

lost in patients with RA and spondyloarthritis (SpA) (Kragstrup et al., 2014), where patients with high disease activity scores have lower plasma sCD18 compared to OA, and thus the potential for elevated levels of leukocyte trafficking (Gjelstrup et al., 2010). Furthermore, B-cells from patients with RA have lost their ability to respond to the adipokine, adiponectin, and therefore their ability to release the peptide hormone, PEPITEM, which acts to limit T-cell migration into inflamed tissues (Chimen et al., 2015). So in addition to lymphocytes acquiring pro-migratory traits, there is also a loss of tonic regulators that normally act to limit tissue infiltration in patients with RA and SpA.

Considering other leukocyte subtypes, patients with RA have higher levels of "reverse migrated" neutrophils in their circulation, suggesting that these cells have sampled the tissue microenvironment and re-entered the circulation across the blood vascular endothelial cells rather than through the lymphatics (Buckley et al., 2006). Moreover, expression of RA susceptibility gene, PTPN22W, enhanced neutrophil migration across $\mathrm{TNF} \alpha$-activated endothelium in vitro (Bayley et al., 2015) and may account for the rapid transit of neutrophils through the rheumatoid joint into the synovial fluid. RA neutrophil chemotaxis toward the synovial fluid rich CXCL8 (IL-8) was blocked with the Janus kinase inhibitors (JAKi) (Mitchell et al., 2017), along with reduced neutrophil and T-cell numbers observed in the joints of RA patients treated with barictinib (Tanaka et al., 2018) - suggesting JAKi have potential therapeutic benefit by limiting leukocyte migration in arthritic patients. The higher expression the $\alpha_{M}$ subunit of the $\alpha_{M} \beta_{2}$-integrin on monocytes from RA patients contributed to their enhanced adhesion to resting (uninflamed) and IL$1 \beta$ stimulated endothelium in vitro when compared to the levels observed for monocytes from normal controls (Lioté et al., 1996). By contrast, fewer fluorescently labeled monocytes migrated through TNF $\alpha$ activated human dermal microvascular endothelial cells when they were isolated from PsA patients, compared to monocytes from patients with osteoarthritis, fibromyalgia or type-2-diabetes (as controls) - most likely due to a reduction in surface expression of the $\alpha_{M} \beta_{2}$-integrin required for stable/firm adhesion, explaining the reduced number of monocytes in the psoriatic joint, compared to RA (Neumüller et al., 2001). Akin to lymphocytes, pathological alterations in the expression of the $\beta_{2}$-integrins by neutrophils and monocytes contribute to the synovial leukocyte composition in these inflammatory arthritides.

Synovial blood vascular endothelial cells (sEC) act as the gatekeepers to the joint. Crucially, Abbot et al. (1999) demonstrated that sEC from RA patients are imprinted with a disease-specific tissue memory and are in a pre-primed state that is maintained in culture. This pathogenic phenotype enables $\mathrm{TNF} \alpha$-stimulated rheumatoid sEC to support greater levels of neutrophil and T-cell capture from flow and induced stable adhesion (Abbot et al., 1999). Further research examining the phenotype of sEC through the evolution of inflammatory arthritides, across diseases and its impact on the inflammatory infiltrate is urgently required. Similarly, synovial fibroblasts from inflammatory arthritides are epigenetically imprinted with a 


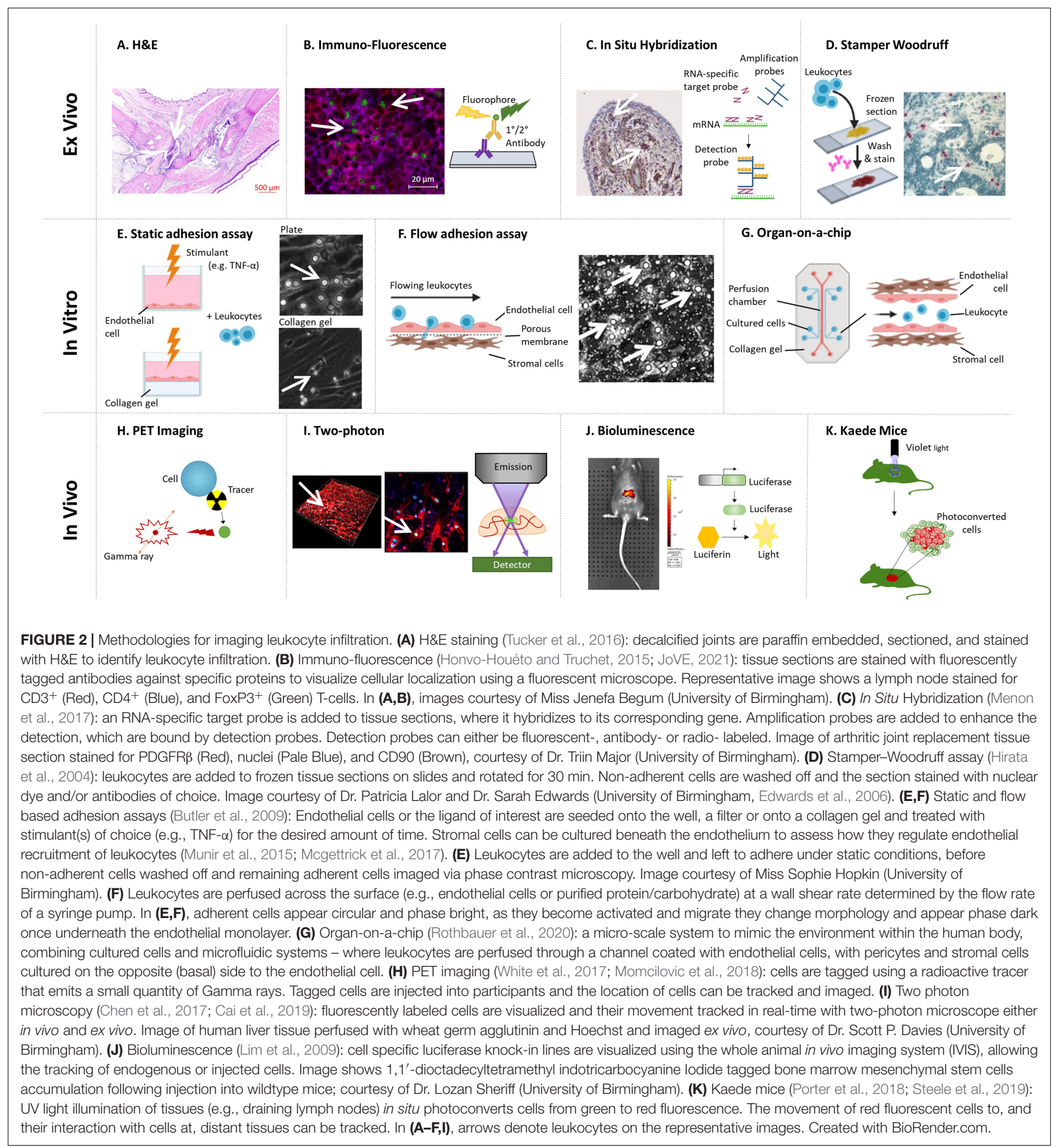

pathogenic phenotype (Parsonage et al., 2005). For example, RA synovial fibroblasts support elevated levels of B-cell (Shimaoka et al., 1998; Burger et al., 2001) and T-cell (Bradfield et al., 2003) pseudoemperipolesis (sub-fibroblast migration) in a CXCL12 dependent manner compared to dermal fibroblasts. Further to this, peripheral blood $\mathrm{CD}^{+}$T-cells from RA patients exhibit higher expression of the $\alpha 6$ integrin subunit and were more efficiently captured from flow to the extracellular matrix components, laminin and fibronectin, than control cells (Haworth et al., 2008). These interactions are likely to be responsible for localizing $\mathrm{CD} 4{ }^{+}$T-cells in the laminin bordered perivascular cuff in the rheumatoid joint (Haworth et al., 2008) as observed by confocal microscopy on tissue sections. Whilst neutrophils from healthy controls and clinically active RA bind 
at similar levels to fibronectin in vitro, significantly fewer cells adhered when they were isolated from patients in clinical remission - these observations were linked to reductions in the expression of L-selectin and $\alpha_{\mathrm{L}}$-integrin on neutrophils following anti-TNF $\alpha$ therapy (Dominical et al., 2011). These studies start to elucidate the molecular mechanisms responsible for leukocyte interactions in the subendothelial space, and how these are altered by drug-induced clinical remission.

The combination of altered adhesive and migratory properties of leukocytes and endothelial cells in patients with RA further amplifies the aberrant trafficking of inflammatory cells during disease - the critical question of which cell type becomes dysregulated first remains to be answered.

\section{3-Dimensional Models}

Over the last 20 years, considerable effort has been made to address the limitations of 2-D culture systems in an attempt to generate a more representative $3-\mathrm{D}$ model of the tissue (McGettrick et al., 2012; Buckley and McGettrick, 2018), in which leukocyte trafficking under static and physiological flow conditions can be observed (Munir et al., 2015; Mcgettrick et al., 2017) (Figure 2F). As a result, it is clear that tissue-resident stromal cells communicate with the neighboring endothelial cells to generate "stromal address codes" for tissue-specific and disease-specific regulation of leukocyte trafficking (Parsonage et al., 2005). Crucially the absence of these signals results in lymphocyte migration being frustrated, such that they shuttle back and forth across the inflamed endothelial barrier, with few cells penetrating a $400 \mu \mathrm{m}$ deep collagen gel (McGettrick et al., 2008; Jeffery et al., 2013). A series of studies using phase-contrast microscopy has revealed that primary synovial fibroblasts from patients with acutely resolving synovitis or primary dermal fibroblasts from patients with RA undergoing joint replacement surgery limit the ability of endothelial cells to recruit lymphocytes from flow - in effect acting in an antiinflammatory manner (McGettrick et al., 2009; Filer et al., 2017). By contrast, synovial fibroblasts from patients with RA undergoing joint replacement surgery were able to stimulate the endothelium, such that they were able to recruit neutrophils and lymphocytes in the absence of any other exogenous cytokines thus exerting a pro-inflammatory action (Rainger et al., 2001; Lally et al., 2005; Smith et al., 2008; McGettrick et al., 2009; Filer et al., 2017). In particular, this response was due to the trafficking and presentation of fibroblast-derived chemokines (CXCL5 and CXCL12) on the endothelial surface, and enhanced leukocyte capture mediated through P-selectin (neutrophils) and $\alpha_{4} \beta_{1^{-}}$ integrin-VCAM-1 interactions (lymphocytes) (Lally et al., 2005; McGettrick et al., 2009). Interestingly the synovial fibroblasts from patients at the earliest phase of RA communicate with the endothelium in a manner that is distinct from fibroblasts isolated from resolving synovitis (i.e., they do not suppress cytokineinduced lymphocyte recruitment), and also from fibroblasts from patients with RA undergoing joint replacement surgery [i.e., they are unable to activate the endothelium to recruit leukocytes in the absence of cytokines (Filer et al., 2017)] - this crucially reveals that the cross-talk, and therefore the patterns of leukocyte trafficking in RA, evolve as the disease progresses and suggest that therapies targeting these processes should also change as the disease evolves. Furthermore, blocking either hydrocortisone or IL-6 was able to reverse the pro-inflammatory effects of fibroblasts from patients with RA who had to undergo joint replacement surgery (Lally et al., 2005; Smith et al., 2008; McGettrick et al., 2009), adding further evidence to the mode of action of glucocorticoid or tocilizumab therapy in these patients. Of note, all these studies focused on the interaction of fibroblasts from patients with inflammatory arthritis with endothelial cells isolated from healthy donors. Additional studies are now required to expand this further by incorporating patient-derived sEC's that exhibit disease-specific phenotypes (as highlighted above) and to elucidate the impact this has on the ability of fibroblasts to regulate leukocyte trafficking. Furthermore, there is also a need to broaden the inflammatory arthritides from which cells are isolated to reveal those features of arthritis that are shared across a range of arthritides and those that are unique.

\section{IMAGING LEUKOCYTE TRAFFICKING IN VIVO - OBSERVATIONAL STUDIES}

The regulation of leukocyte trafficking is multifactorial involving blood flow; endothelial and stromal responses. Similarly, inflammatory arthritides can be systemic diseases, affecting multiple joints and other organ systems. The only way to truly understand how arthritic pathology influences the kinetics, spatial location and molecular mechanisms of leukocyte migration into, through and away from the joint is through in vivo analysis - either preclinical murine models of disease or imaging of patients joints. However, these approaches are significantly more complicated than those we have discussed above, due to the intricate nature of joints (Gompels et al., 2010). As a result, most studies to date have focused on mapping cellular movement, with few conducting mechanistic investigations.

Initial efforts to observe infiltration of human leukocytes movement in real-time began by metal-tagging purified leukocytes subsets and re-injecting them back into the subject, allowing the small gamma particles released by the tagged cells to be detected and tracked (Uno et al., 1986; Dudhia et al., 2015). Tagging human leukocytes with indium-111 ( $\left.{ }^{111} \mathrm{In}\right)$ revealed the accumulation of tagged cells in the joints of human patients with swelling and active RA, which were not observed in patients where swelling and pain were not present (Uno et al., 1986) or those with inactive disease (Uno et al., 1992). Moreover, anti-TNF $\alpha$ therapy reduced ${ }^{111}$ In-labeled granulocyte trafficking into patient joints over $22 \mathrm{~h}$ (Taylor et al., 2000). Techniques subsequently progressed to enable tagging of specific cell types, such as anti-T-cell (CD3) technetium-99m $\left({ }^{99 m} \mathrm{Tc}\right)$ tagged antibodies, which were observed accumulating in the moderately or severely painful joints in RA and PsA patients, but not in those joints where pain levels were low or absent (Marcus et al., 1994). Indeed, clinically active and inactive joints have also been identified using radiolabeled E-selectin in patients with RA (Chapman et al., 1994; Chapman et al., 1996; Jamar et al., 2002). Once again, anti-TNF- $\alpha$ therapy (adalimumab) decreased ${ }^{99} \mathrm{~m}$ Tc-labeled leukocyte accumulation 
into the joints of RA patients 2 weeks after the treatment onset, which subsequent studies suggested that this was due to increased ${ }^{99 m} \mathrm{Tc}$ monocyte/macrophage egress from the joint as numbers of monocytes entering remained unaffected by adalimumab treatment (Thurlings et al., 2009; Herenius et al., 2011). Similarly, metal tagged antibodies against E-selectin have also revealed its up-regulation in porcine arthritic joints but not control joints (Chapman et al., 1994). Thus linking the active movement of T-cells into the joint and changes in capture receptor expression with swelling, pain and disease activity experienced by the patients. Similarly, blood neutrophils tagged with technetium-99m hexametazime were observed ingressing into the rheumatoid joint over $22 \mathrm{~h}$ by gamma camera imaging, a response that was blocked by glucocorticoid therapy (methylprednisolone) (Youssef et al., 1996). By contrast, when synovial fluid neutrophils tagged with ${ }^{111}$ In were injected intra-articularly their egress from the synovial space into the periphery was unaffected by methylprednisolone treatment (Youssef et al., 1996). Further supporting the involvement of migrating neutrophils in the RA pathology, and the beneficial action of glucocorticoid therapy on limiting their movement/effector functions.

Positron emission tomography (PET) tracers allow a noninvasive means to measure cellular accumulation (White et al., 2017; Momcilovic et al., 2018) (Figure 2H). For instance, higher levels of the PET tracer $[18 \mathrm{~F}] \mathrm{F}-\mathrm{AraG}$ were detected in the arthritic paws of AIA mice, whilst no tracer was observed in control paws (Franc et al., 2017). Similarly, in RA and PsA patients, the [18F]-FDG PET tracer was shown to accumulate at sites of synovitis, but not in unaffected joints (Chaudhari et al., 2016). Thus, indicating an accumulation of activated immune cells in the arthritic joint, which could result from either increased leukocyte migration or enhanced proliferation of the cells within the tissue or a combination of both. Protein specific PET tracers, such as ${ }^{68} \mathrm{Ga}$-Aquibeprin or ${ }^{68} \mathrm{Ga}$-Avebetrin that bind specifically to $\alpha_{5} \beta_{1}$-integrin or $\alpha_{V} \beta_{3}$-integrin, respectively, can also be used to track the expression pattern of molecules involved in leukocyte trafficking (Notni et al., 2019). Such tracers showed increased expression of $\alpha_{5} \beta_{1}$ - and $\alpha_{V} \beta_{3}$-integrins in arthritic joints compared to non-arthritic joints in mice with CIA (Notni et al., 2019), suggesting arthritis increases the expression of these integrins to facilitate leukocyte accumulation. Tracer studies are currently limited to detecting global cellular activity (accumulation/proliferation) but are unable to identify individual cells or subsets or their movement.

The greatest advancement in imaging the dynamics of leukocyte trafficking in vivo has come from the development of two-photon microscopy, which allows tissues, including the joints and blood vessels, of living organisms to be imaged in real-time enabling the observer to visualize specific parts of the adhesion cascade including velocities (Chen et al., 2017; Cai et al., 2019) (Figure 2I). For example, leukocyte rolling and adhesion to arthritic joints (Veihelmann et al., 1999), or neighboring tendons [achilles and patella (Gál et al., 2005)], increased in a time-dependent manner in the initial phases of the disease, after which the number (Veihelmann et al., 1999) and velocity (Gál et al., 2005) of rolling cells steadily declined, whilst the absolute numbers of adherent cells remained elevated in both AIA and proteoglycan induced arthritis (PGIA) models relative to the control animals. Moreover, rolling velocities increased at early time points $(4 \mathrm{~h})$ and absolute numbers of adherent leukocytes were reduced over the first $24 \mathrm{~h}$ in L-selectin knockout mice with AIA - observed using intravital microscopy of the synovial post-capillary venules (Szántó et al., 2004). Similarly, more LysMeGFP granulocytic myeloid cells were observed moving at a much slower mean migration velocity through metatarsal tissue of AIA mice using intravital microscopy compared to controls (Byrne et al., 2012). Moreover, adoptively transferred fluorescently labeled antigen-presenting cells (APC) isolated from the spleen and draining lymph nodes of PGIA mice were detected inside the ankles of severe combined immunodeficient (SCID) mice by multiphoton imaging (Angyal et al., 2010). However, when splenic T-cells were transferred they were only detected in the lymph nodes, revealing low levels of T-cell migration directly into the joint following induction of PGIA (Angyal et al., 2010). Nearinfrared whole animal imaging tracked the increased infiltration of $\mathrm{F} 4 / 80^{+}$monocyte/macrophages into arthritic joints over the first $6 \mathrm{~h}$ of AIA (Hansch et al., 2004). Taking this further, biofluorescence whole animal imaging studies revealed the more effective localization of anti-TNF $\alpha$ drugs (certolizumab pegol, adalimumab, and infliximab) to arthritic joints than non-arthritic joints in mice with CIA (Palframan et al., 2009).

Alternative strategies employing the use of bioluminescence, commonly involving luciferase, avoid the need for excitation of the label of interest (Figure 2J). For instance, Nakajima et al. (2001) tracked the localization of type-II collagen specific GFP-luciferase CD4 T-cell hybridomas following their injection into mice with CIA using whole animal real-time live bioluminescence imaging with the in vivo imaging system (IVIS) over a 7 days period (Nakajima et al., 2001). Initially GFP-luciferase CD4 T-cells were observed accumulating in the lungs after $24 \mathrm{~h}$, but subsequently moved to the arthritic joints where the intensity of GFP-luciferase signal, and therefore the accumulation of cells, increased between 3 and 5 days and was still detectable at the same level 7 days post-injection (Nakajima et al., 2001). Using this technology, the locations of specific cell types can be observed throughout an experiment, however, it does not provide detailed data outlining specific cell numbers.

Advances in photoconvertible reporter mice (e.g., Kaede) are now allowing us to gain some insights into the migratory journey of leukocytes to and from tissues. For example, in Kaede mice, cells are converted from green to red fluorescence with a UV light, allowing researchers to track the movement of cells from the tissue of photoconversion into distance sites (Porter et al., 2018; Steele et al., 2019) (Figure 2K). On a technical note, it is crucial that tissues neighboring the photoconversion site are appropriately shielded from the light source to avoid converting these cells also. Whilst there are currently no publications reporting photoconversion of an inflamed joint or the neighboring draining lymph nodes we are aware of several groups working in this area and await the outcome of these studies. That said, groups have photoconverted areas of the small intestine and colon in arthritic mice (CIA and KRN, respectively) and detected converted cells, mainly $\mathrm{CD} 4^{+} \mathrm{T}$-cells, in the joint 
and the draining lymph node between 1 (Morton et al., 2014) and 4 days (Tajik et al., 2020) later by flow cytometry. Combining these data with the earlier IHC studies from the late 1990s further confirms the importance of the ability of gut-derived leukocytes to migrate into arthritic joints in the pathogenesis of the disease.

Whilst advancements in imaging technologies allow the dynamics of leukocyte trafficking patterns or the expression profile of adhesion molecules and cytokines to be observed in vivo, we are not yet in the position to fully track these processes in patients over their disease and treatment journey. Improving imaging of molecular mechanistic changes, such as alterations in receptors and ligands, that occur as leukocytes enter and exit the joint is essential to fully understanding these processes and to identify targets to limit trafficking of pathogenic leukocytes whilst promoting the movement of regulatory leukocytes necessary to resolve the inflammatory response and repair the damaged joint.

\section{SUMMARIZING OUR CURRENT UNDERSTANDING OF THE MECHANISMS DRIVING INFLAMMATORY ARTHRITIS}

It is clear that patients with inflammatory arthritides, such as RA or PsA, have defects in one or more of the security checkpoints that normally regulate leukocyte trafficking (Buckley and McGettrick, 2018) (Figure 3). Firstly synovial endothelial cells (Abbot et al., 1999) and fibroblasts (Parsonage et al., 2005) are imprinted with a pathogenic pro-inflammatory phenotype that is maintained in culture, and which causes these cells to express elevated levels of proinflammatory and pro-recruitment mediators, such as adhesion molecules, chemokines, lipids and cytokines (Parsonage et al., 2005). Moreover, synovial endothelial cells acquire tissue-specific traits associated with mucosal endothelium (VAP-1) (Salmi et al., 1997) and high endothelial venules (PNAd) (Salmi et al., 1997; Cañete et al., 2007) allowing the aberrant trafficking of gut-homing and lymph node homing leukocytes to the joints, and in some cases the formation of tertiary lymphoid structures (Morton et al., 2014; Tajik et al., 2020). Synovial fibroblasts also display positional memory for their location within a joint (Croft et al., 2019; Wei et al., 2020), and differ across joints (Frank-Bertoncelj et al., 2017) - this adds further complexity to the regulation of leukocyte migration within the synovium itself, and for which newer imaging modalities are just starting to reveal insights. Finally, the bi-directional cross-talk between endothelial cells and fibroblasts evolves as the disease progresses (Filer et al., 2017), altering the composition of leukocytes in the joint over the disease history. Thus pathogenic changes in the joint tissue microenvironment actively support the aberrant leukocyte trafficking and accumulation, and so one strategy would be to reset the tissue microenvironment to reverse pathology. Yet, leukocytes from these patients can also display pro-adhesive, promigratory phenotypes, linked to genetics [e.g., PTPN22W (Bayley et al., 2015; Burn et al., 2016)], altered metabolism (Pucino et al., 2019, 2020) or protein expression [adiponectin receptors
(Chimen et al., 2015); TSK5 (Shen et al., 2017)], which tend to lead to enhanced or prolonged $\alpha_{\mathrm{L}} \beta_{2}$-integrin expression (Yokota et al., 1995; Burn et al., 2016) facilitating their entry and retention within the inflamed joint. However, this raises the "chicken and egg" question of whether changes in the tissue or changes in leukocytes are the first to happen. Of note, we know much more about the molecular mechanism governing these processes in the context of RA, than other inflammatory arthritides.

Many imaging studies using a wide range of technologies have demonstrated the significant role TNF $\alpha$ plays in the initiation and propagation of inflammation in the joints of humans with RA (Barrera et al., 2001) and mice (Williams et al., 1992; SudołSzopińska et al., 2013). Of relevance here is the reduction in leukocyte accumulation in arthritic joints, as well as changes in the expression of adhesion molecules [e.g., E-selectin and VCAM-1 (Tak et al., 1996)] and chemokines (e.g., IL-8) (Butler et al., 1995) in response to TNFa inhibitors. Despite this, not all RA patients respond to the various on the market, which might be explained, at least in part, by the distinct synovium leukocyte pathotypes observed in tissue sections from patients (Nerviani et al., 2020). Few, if any studies have examined leukocyte numbers or expression of key molecules involved in the recruitment cascade for other chemical or biological disease-modifying antirheumatic drugs (DMARDs). Understanding how DMARDs impact the key components and cells of the cascade will allow the mechanism of initiation, development and resolution of inflammatory arthritides to be identified, possibly leading to personalized medicine depending on disease stage.

\section{THE FUTURE OF THE IN VITRO JOINT}

Technologies to make more in vivo-like constructs are continuing to vastly improve: ranging from 3 -D self-organizing tissue culture organoids; through to microfluidic channels and building up to 3-D cell cultures incorporating microfluidic technology to create organs-on-chips, and finally the fabrication of tissue-like structures. All of these techniques have improved tremendously over the past 10 years, but their use in studies of leukocyte trafficking in the context of inflammatory arthritides remains limited (reviewed by Damerau and Gaber, 2020).

Given inflammatory arthritides are driven by multiple cellcell interactions, 3-D organoids offer an excellent way of interrogating these communication pathways in more detail. Unfortunately, the 3-D nature of these constructs currently restricts the possibility of real-time live imaging, so these models are commonly analyzed upon sectioning as seen for whole tissue. For example, TNF $\alpha$ induced the self-organization and proliferation of a 3-D micromass of fibroblast-like synoviocytes from RA patients into the two distinct layers found in the joint (a lining and sublining layer), implying fibroblasts maintain positional memory in culture enabling them to organize themselves as seen in the joint (Calvo et al., 2017). Building upon this, organoids consisting of fibroblasts and endothelial cells suspended in a matrigel droplet revealed that up-regulation of $\mathrm{NOTCH} 3$ ligands on the vasculature help to drive the spatial organization of fibroblasts into lining and sublining layers, where 


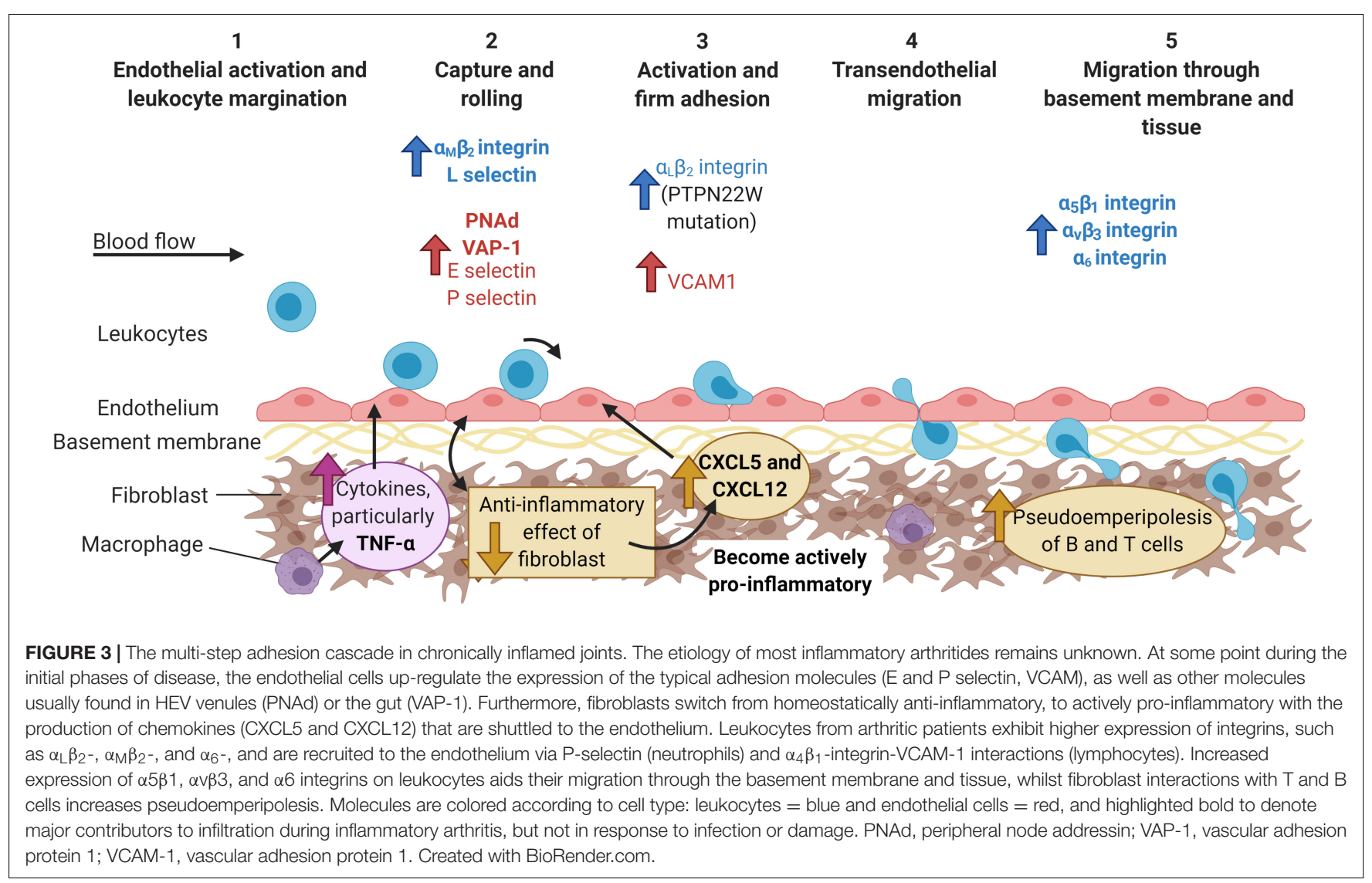

deletion of NOTCH3 reduced the clinical score and inflammatory infiltrated observed by H\&E in mice with STIA (Wei et al., 2020). Crucially a subpopulation of synovial fibroblast (fibroblast activation protein $\alpha+; \operatorname{FAP} \alpha+)$ is responsible for driving leukocyte infiltration in STIA mice, where deleting FAP $\alpha+$ fibroblasts reduced leukocyte numbers in the arthritic joint (Croft et al., 2019). Collectively these studies highlight the importance of fibroblast subtypes in regulating leukocyte trafficking and the ability of endothelial cells to influence the phenotype of the neighboring stroma, but crucially they demonstrate the possibility of modeling the human diseased joint using fibroblastendothelial cell 3-D organoids in vitro. Of note, tumor and mural organoid models incorporating mesodermal progenitor cells were able to form a hierarchical structure of blood vessels (Wörsdörfer et al., 2019), suggesting the same could be done and used to model the vasculature in inflammatory arthritides.

Advances in 3-D printing are driving forward the field of microfluidic modeling of leukocyte recruitment in a disease context (Sackmann et al., 2012; Venugopal Menon et al., 2018), where incorporating precious, but limited, patient material into high-throughput mechanistic screening studies is becoming a reality. Such systems have effectively mimicked the disturbed flow patterns seen in vessel bifurcations, highlighting these as areas where endothelial cells can support the recruitment of the monocyte cell line, THP-1 - as seen in atherosclerosis (Khan and Sefton, 2011). Hence microfluidic channels may help to elucidate the disparities seen in the vascular patterns in patients with PsA and RA (Kennedy et al., 2010). Addition of collagen scaffolds; tuneable chemical gradients ( $\mathrm{Wu}$ et al., 2017) and stromal cells, to the microfluidic channels are paving the way for the development of personalized "organs-on-a-chip" which present the possibility of precision medicine (Van Den Berg et al., 2019). In the context of inflammatory arthritis, microfluidic systems have been used to track the migration of the cadherin-11 expressing synovial cell line (SW982) toward an activated osteoclast cell line (RAW264.7), where the co-culture construct enhanced SW982 migration and osteoclast activity compared to the monocultures (Ma et al., 2018). Moreover, 3-D "synovium-on-a-chip" with an integrated time-resolved light scatter biosensor has been generated that allows the visualization of $\mathrm{TNF} \alpha$ induced fibroblast organization into lining and sublining layers over 2 days (Rothbauer et al., 2020) (e.g., Figure 2G). Incorporating endothelial cells and leukocytes into such models would enable in vivo like analysis of recruitment and it is most likely only a matter of time before these are generated. Furthermore, other in vivo like constructs are being formed, such as the living vascular tissue fabricated by direct culture of collagen, smooth muscle cells and endothelial cells, presenting another way to move away from in vivo models, whilst accessing leukocyte infiltration (Meghezi et al., 2015). These studies highlight how rapidly microfluidic and in vivo models are improving, providing the opportunity to access multiple cell:cell interactions, whilst also mimicking physiological aspects such as blood flow. This is crucial in understanding inflammatory 
diseases such as RA, PsA and IA, which are known to be driven by uncontrolled leukocyte recruitment, but exactly how and why this occurs is yet to be elucidated.

The era of precision medicine for inflammatory arthritis is fast approaching (reviewed by Aletaha, 2020; Miyagawa and Tanaka, 2020) with "big data" providing insights into different patient populations and further subgrouping patients according to their underlying process driven pathology - yet imaging remains crucial for initial discoveries and confirming outputs of omics analysis (e.g., Lewis et al., 2019). Indeed, the use of synovial tissue signatures improves the prediction that a patient will require biological therapy 12 months after diagnosis (Lliso-Ribera et al., 2019). Furthermore, advances in spatial transcriptomics now enables mapping of gene expression profiles onto images of tissues, providing for the first-time spatial context to gene expression data (Burgess, 2019). Such technology has revealed that central memory T-cells were dominant in RA synovial tissue sections, whilst in SpA tissues effector memory T-cells were most prominent (Carlberg et al., 2019), and thus will enable more targeted therapies to be delivered to these patients in the future. Advances in imaging technologies, in particular the "synovium-on-a-chip" described above, incorporating patient synovial material provides the opportunity to pre-screen possible treatment options based on identified "patient specific signatures," ultimately offering the realistic hope of achieving precision medicine for all patients based on their cellular and molecular processes driving their disease pathology.

\section{CONCLUSION}

Significant advances in imaging modalities over the last 60 years have vastly improved our understanding of leukocyte infiltrates in the inflamed joints in numerous inflammatory arthritides in patients as well as in vitro/in vivo models. It is evidently clear that the local microenvironment of an inflamed joint dictates the spatiotemporal dynamics of leukocyte entry and egress, and it is highly likely this differs in different regions of a given

\section{REFERENCES}

Abbot, S. E., Whish, W. J. D., Jennison, C., Blake, D. R., and Stevens, C. R. (1999). Tumour necrosis factor $\alpha$ stimulated rheumatoid synovial microvascular endothelial cells exhibit increased shear rate dependent leucocyte adhesion in vitro. Ann. Rheum. Dis. 58, 573-581. doi: 10.1136/ard.58.9.573

Aletaha, D. (2020). Precision medicine and management of rheumatoid arthritis. J. Autoimmun. 110:102405. doi: 10.1016/j.jaut.2020.102405

Alivernini, S., Tolusso, B., Petricca, L., Bui, L., Di Sante, G., Peluso, G., et al. (2017). Synovial features of patients with rheumatoid arthritis and psoriatic arthritis in clinical and ultrasound remission differ under anti-TNF therapy: a clue to interpret different chances of relapse after clinical remission? Ann. Rheum. Dis. 76, 1228-12396. doi: 10.1136/annrheumdis-2016-210424

Angyal, A., Egelston, C., Kobezda, T., Olasz, K., László, A., Glant, T. T., et al. (2010). Development of proteoglycan-induced arthritis depends on $\mathrm{T}$ cell-supported autoantibody production, but does not involve significant influx of T cells into the joints. Arthritis Res. Ther. 12:R44.

Baeten, D., De Keyser, F., Demetter, P., Cuvelier, C., Van den Bosch, F., Kruithof, E., et al. (2000). Comparative study of the synovial histology in rheumatoid joint, between patients, as the disease evolves and in response to treatments. Despite our advances, there is still much we do not fully understand particularly in the context of human disease, and for that further advances are needed to image these processes directly in patients but more realistically to enable the imaging of complex in vitro constructs of a patient's joint microenvironment. Only then will we be able to truly map the spatiotemporal dynamics and molecular mechanisms for a patient at a given time point in their disease history. Ultimately the aim would be to develop drug combinations that can limit the trafficking of pathogenic effector leukocytes whilst promoting the function and presence of regulatory leukocytes to switch off the inflammatory response and induce clinical remission/cure the disease.

\section{AUTHOR CONTRIBUTIONS}

All authors listed have made a substantial, direct and intellectual contribution to the work, and approved it for publication.

\section{FUNDING}

JM, JL, and L-JM were supported by Ph.D. studentships funded by MRC iCase (MR/P016154/1); MRC-Versus Arthritis Centre for Musculoskeletal Ageing Research Ph.D. studentship (MR/R502364/1); and Kennedy Trust for Rheumatology Research, respectively. This work was also supported by MRC project grant MR/T028025/1.

\section{ACKNOWLEDGMENTS}

We would like to extend our thanks to our colleagues at the University of Birmingham, United Kingdom whom kindly provided representative images obtained from the techniques detailed in Figure 2: Miss Jenefa Begum, Dr. Scott P. Davies (NC3Rs - NC/R002061/1), Dr. Sarah Edwards, Dr. Triin Major, Dr. Patricia Lalor, Miss Sophie Hopkin, and Dr. Lozan Sheriff. arthritis, spondyloarthropathy, and osteoarthritis: influence of disease duration and activity. Ann. Rheum. Dis. 59, 945-953. doi: 10.1136/ard.59.12.945

Barrera, P., Joosten, L. A. B., Den Broeder, A. A., Van de Putte, L. B. A., Van Riel, P. L. C. M., and Van den Berg, W. B. (2001). Effects of treatment with a fully human anti-tumour necrosis factor $\alpha$ monoclonal antibody on the local and systemic homeostasis of interleukin 1 and TNF $\alpha$ in patients with rheumatoid arthritis. Ann. Rheum. Dis. 60, 660-669. doi: 10.1136/ard.60. 7.660

Bayley, R., Kite, K. A., McGettrick, H. M., Smith, J. P., Kitas, G. D., Buckley, C. D., et al. (2015). The autoimmune-associated genetic variant PTPN22 R620W enhances neutrophil activation and function in patients with rheumatoid arthritis and healthy individuals. Ann. Rheum. Dis. 74, 1588-1595. doi: 10. 1136/annrheumdis-2013-204796

Behrens, F., Himsel, A., Rehart, S., Stanczyk, J., Beutel, B., Zimmermann, S. Y., et al. (2007). Imbalance in distribution of functional autologous regulatory $\mathrm{T}$ cells in rheumatoid arthritis. Ann. Rheum. Dis. 66, 1151-1156. doi: 10.1136/ard.2006. 068320

Bradfield, P. F., Amft, N., Vernon-Wilson, E., Exley, A. E., Parsonage, G., Rainger, G. E., et al. (2003). Rheumatoid fibroblast-like synoviocytes 
overexpress the chemokine stromal cell-derived factor 1 (CXCL12), which supports distinct patterns and rates of CD4+ and CD8+ T cell migration within synovial tissue. Arthritis Rheum. 48, 2472-2482. doi: 10.1002/art. 11219

Buckley, C. D., and McGettrick, H. M. (2018). Leukocyte trafficking between stromal compartments: lessons from rheumatoid arthritis. Nat. Rev. Rheumatol. 14, 476-487. doi: 10.1038/s41584-018-0042-4

Buckley, C. D., Ross, E. A., McGettrick, H. M., Osborne, C. E., Haworth, O., Schmutz, C., et al. (2006). Identification of a phenotypically and functionally distinct population of long-lived neutrophils in a model of reverse endothelial migration. J. Leukoc. Biol. 79, 303-311. doi: 10.1189/jlb.09 05496

Burger, J. A., Zvaifler, N. J., Tsukada, N., Firestein, G. S., and Kipps, T. J. (2001). Fibroblast-like synoviocytes support B-cell pseudoemperipolesis via a stromal cell-derived factor-1- and CD106 (VCAM-1)-dependent mechanism. J. Clin. Invest. 107, 305-315. doi: 10.1172/jci11092

Burgess, D. J. (2019). Spatial transcriptomics coming of age. Nat. Rev. Genet. 20:317. doi: 10.1038/s41576-019-0129-z

Burn, G. L., Cornish, G. H., Potrzebowska, K., Samuelsson, M., Griffié, J., Minoughan, S., et al. (2016). Superresolution imaging of the cytoplasmic phosphatase PTPN22 links integrin-mediated $\mathrm{T}$ cell adhesion with autoimmunity. Sci. Signal. 9:ra99, doi: 10.1126/scisignal. aaf2195

Butler, D. M., Maini, R. N., Feldmann, M., and Brennan, F. M. (1995). Modulation of proinflammatory cytokine release in rheumatoid synovial membrane cell cultures. Comparison of monoclonal anti TNF- $\alpha$ antibody with the interleukin1 receptor antagonist. Eur. Cytokine Netw. 6, 225-230.

Butler, L. M., McGettrick, H. M., and Nash, G. B. (2009). Static and dynamic assays of cell adhesion relevant to the vasculature. Methods Mol. Biol. 467, 211-228. doi: 10.1007/978-1-59745-241-0_12

Byrne, R., Rath, E., Hladik, A., Niederreiter, B., Bonelli, M., Frantal, S., et al. (2012). A dynamic real time in vivo and static ex vivo analysis of granulomonocytic cell migration in the collagen- induced arthritis model. PLoS One 7:e35194. doi: 10.1371/journal.pone.0035194

Cai, C., Zambach, S. A., Fordsmann, J. C., Lønstrup, M., Thomsen, K. J., Jensen, A. G. K., et al. (2019). In vivo three-dimensional two-photon microscopy to study conducted vascular responses by local ATP ejection using a glass micro-pipette. J. Vis. Exp. 148:e59286.

Calvo, I. O., Byrne, R. A., Karonitsch, T., Niederreiter, B., Kartnig, F., Alasti, F., et al. (2017). 04.19 3D synovial organoid culture reveals cellular mechanisms of tissue formation and inflammatory remodelling. Ann. Rheum. Dis. 76(Suppl 1), A49.3-A50.

Campbell-Thompson, M. L., Heiple, T., Montgomery, E., Zhang, L., and Schneider, L. (2012). Staining protocols for human pancreatic islets. J. Vis. Exp. 63:4068.

Cañete, J. D., Santiago, B., Cantaert, T., Sanmartí, R., Palacin, A., Celis, R., et al. (2007). Ectopic lymphoid neogenesis in psoriatic arthritis. Ann. Rheum. Dis. 66, 720-726. doi: 10.1136/ard.2006.062042

Carlberg, K., Korotkova, M., Larsson, L., Catrina, A. I., Ståhl, P. L., and Malmström, V. (2019). Exploring inflammatory signatures in arthritic joint biopsies with spatial transcriptomics. Sci. Rep. 9:18975.

Chapman, P. T., Jamar, F., Harrison, A. A., Binns, R. M., Peters, A. M., and Haskard, D. O. (1994). Noninvasive imaging of e-selectin expression by activated endothelium in urate crystal-induced arthritis. Arthritis Rheum. 37, 1752-1756. doi: 10.1002/art.1780371207

Chapman, P. T., Jamar, F., Keelan, E. T. M., Peters, A. M., and Haskard, D. O. (1996). Use of a radiolabeled monoclonal antibody against e-selectin for imaging of endothelial activation in rheumatoid arthritis. Arthritis Rheum. 39, 1371-1375. doi: 10.1002/art.1780390815

Chaudhari, A. J., Ferrero, A., Godinez, F., Yang, K., Shelton, D. K., Hunter, J. C., et al. (2016). High-resolution 18F-FDG PET/CT for assessing disease activity in rheumatoid and psoriatic arthritis: findings of a prospective pilot study. $\mathrm{Br}$. J. Radiol. 89:20160138. doi: 10.1259/bjr.20160138

Chen, C., Zhang, Y. P., Sun, Y., Xiong, W., Shields, L. B. E., Shields, C. B., et al. (2017). An in vivo duo-color method for imaging vascular dynamics following contusive spinal cord injury. J. Vis. Exp. 130:56565.

Chimen, M., McGettrick, H. M., Apta, B., Kuravi, S. J., Yates, C. M., Kennedy, A., et al. (2015). Homeostatic regulation of T cell trafficking by a B cell-derived peptide is impaired in autoimmune and chronic inflammatory disease. Nat. Med. 21, 467-475. doi: 10.1038/nm.3842

Croft, A. P., Campos, J., Jansen, K., Turner, J. D., Marshall, J., Attar, M., et al. (2019). Distinct fibroblast subsets drive inflammation and damage in arthritis. Nature. 570, 246-251. doi: 10.1038/s41586-019-1263-7

Damerau, A., and Gaber, T. (2020). Modeling rheumatoid arthritis in vitro: from experimental feasibility to physiological proximity. Int. J. Mol. Sci. 21:7916. doi: $10.3390 /$ ijms 21217916

Dijkstra, C. D., Döpp, E. A., Vogels, I. M. C., and Van Noorden, C. J. (1987). Macrophages and dendritic cells in antigen-induced arthritis: an immunohistochemical study using cryostat sections of the whole knee joint of rat. Scand. J. Immunol. 26, 513-523. doi: 10.1111/j.1365-3083.1987.tb0 2285.x

Dominical, V. M., Bértolo, M. B., Almeida, C. B., Garrido, V. T., Miguel, L. I., Costa, F. F., et al. (2011). Neutrophils of rheumatoid arthritis patients on anti$\mathrm{TNF}-\alpha$ therapy and in disease remission present reduced adhesive functions in association with decreased circulating neutrophil-attractant chemokine levels. Scand. J. Immunol. 73, 309-318. doi: 10.1111/j.1365-3083.2011.02503.x

Dudhia, J., Becerra, P., Valdés, M. A., Neves, F., Hartman, N. G., and Smith, R. K. W. (2015). In vivo imaging and tracking of technetium-99m labeled bone marrow mesenchymal stem cells in equine tendinopathy. J. Vis. Exp. 106:e52748.

Dunky, A., Neumüller, J., and Menzel, J. (1997). Interactions of lymphocytes from patients with psoriatic arthritis or healthy controls and cultured endothelial cells. Clin. Immunol. Immunopathol. 85, 297-314. doi: 10.1006/clin.1997.4440

Edwards, S., Lalor, P. F., Tuncer, C., and Adams, D. H. (2006). Vitronectin in human hepatic tumours contributes to the recruitment of lymphocytes in an avß3-independent manner. Br. J. Cancer. 95, 1545-1554. doi: 10.1038/sj.bjc. 6603467

Filer, A., Ward, L. S. C., Kemble, S., Davies, C. S., Munir, H., Rogers, R., et al. (2017). Identification of a transitional fibroblast function in very early rheumatoid arthritis. Ann. Rheum. Dis. 76, 2105-2112. doi: 10.1136/annrheumdis-2017211286

Franc, B. L., Goth, S., MacKenzie, J., Li, X., Blecha, J., Lam, T., et al. (2017). In vivo PET imaging of the activated immune environment in a small animal model of inflammatory arthritis. Mol. Imaging 16:1536012117712638.

Frank-Bertoncelj, M., Trenkmann, M., Klein, K., Karouzakis, E., Rehrauer, H., Bratus, A., et al. (2017). Epigenetically-driven anatomical diversity of synovial fibroblasts guides joint-specific fibroblast functions. Nat. Commun. 8:14852.

Gál, I., Bajnok, É, Szántó, S., Sarraj, B., Glant, T. T., and Mikecz, K. (2005). Visualization and in situ analysis of leukocyte trafficking into the ankle joint in a systemic murine model of rheumatoid arthritis. Arthritis Rheum. 52, 3269-3278. doi: 10.1002/art.21532

Gjelstrup, L. C., Boesen, T., Kragstrup, T. W., Jørgensen, A., Klein, N. J., Thiel, S., et al. (2010). Shedding of large functionally active CD11/CD18 integrin complexes from leukocyte membranes during synovial inflammation distinguishes three types of arthritis through differential epitope exposure. J. Immunol. 185, 4154-4168. doi: 10.4049/jimmunol.1000952

Gompels, L. L., Lim, N. H., Vincent, T., and Paleolog, E. M. (2010). In vivo optical imaging in arthritis-an enlightening future? Rheumatology (Oxford) 49, 1436-1446. doi: 10.1093/rheumatology/keq012

Gonçalves, W. A., Rezende, B. M., de Oliveira, M. P. E., Ribeiro, L. S., Fattori, V., da, Silva WN, et al. (2020). Sensory ganglia-specific TNF expression is associated with persistent nociception after resolution of inflammation. Front. Immunol. 10:3120. doi: 10.3389/fimmu.2019.03120

Grober, J. S., Bowen, B. L., Ebling, H., Athey, B., Thompson, C. B., Fox, D. A., et al. (1993). Monocyte-endothelial adhesion in chronic rheumatoid arthritis: In situ detection of selectin and integrin-dependent interactions. J. Clin. Invest. 91, 2609-2619. doi: 10.1172/jci116500

Hansch, A., Frey, O., Sauner, D., Hilger, I., Haas, M., Malich, A., et al. (2004). In vivo imaging of experimental arthritis with near-infrared fluorescence. Arthritis Rheum. 50, 961-967. doi: 10.1002/art.20112

Harlan, J. M. (1993). Leukocyte adhesion deficiency syndrome: insights into the molecular basis of leukocyte emigration. Clin. Immunol. Immunopathol. 67, S16-S24.

Haworth, O., Hardie, D. L., Burman, A., Rainger, G. E., Eksteen, B., Adams, D. H., et al. (2008). A role for the integrin $\alpha 6 \beta 1$ in the differential distribution of CD4 
and CD8 T-cell subsets within the rheumatoid synovium. Rheumatology 47, 1329-1334. doi: 10.1093/rheumatology/ken263

Herenius, M. M. J., Thurlings, R. M., Wijbrandts, C. A., Bennink, R. J., Dohmen, S. E., Voermans, C., et al. (2011). Monocyte migration to the synovium in rheumatoid arthritis patients treated with adalimumab. Ann. Rheum. Dis. 70, 1160-1162. doi: 10.1136/ard.2010.141549

Hirata, T., Furie, B. B. C., and Furie, B. B. C. (2004). "Lymphocyte homing to the skin," in Lymphocyte Homing to the Skin: Immunology, Immunopathology, and Therapeutic Perspectives, ed. W.-H. Boehncke (Boca Raton, FL: CRC Press), 53-88. doi: 10.1201/b15729-4

Honvo-Houéto, E., and Truchet, S. (2015). Indirect immunofluorescence on frozen sections of mouse mammary gland. J. Vis. Exp. 16:53179.

Humby, F., Lewis, M., Ramamoorthi, N., Hackney, J. A., Barnes, M. R., Bombardieri, M., et al. (2019). Synovial cellular and molecular signatures stratify clinical response to csDMARD therapy and predict radiographic progression in early rheumatoid arthritis patients. Ann. Rheum. Dis. 78, 761772. doi: 10.1136/annrheumdis-2018-214539

Jamar, F., Houssiau, F. A., Devogelaer, J. P., Chapman, P. T., Haskard, D. O., Beaujean, V., et al. (2002). Scintigraphy using a technetium 99m-labelled antiE-selectin Fab fragment in rheumatoid arthritis. Rheumatology 41, 53-61. doi: 10.1093/rheumatology/41.1.53

Jeffery, H. C., Buckley, C. D., Moss, P., Rainger, G. E., Nash, G. B., and McGettrick, H. M. (2013). Analysis of the effects of stromal cells on the migration of lymphocytes into and through inflamed tissue using 3-D culture models. J. Immunol. Methods 400-401, 45-57. doi: 10.1016/j.jim.2013.10.004

Johnson, B. A., Haines, G. K., Harlow, L. A., and Koch, A. E. (1993). Adhesion molecule expression in human synovial tissue. Arthritis Rheum. 36, 137-146. doi: 10.1002/art.1780360203

JoVE (2021). Protocol for Immunofluorescence Staining of Paraffin Tissue Sections [Internet]. Available online at: https://www.jove.com/v/10500/ immunofluorescence-microscopy-immunofluorescence-staining-paraffin (accessed January 29, 2021).

Kennedy, A., Ng, C. T., Biniecka, M., Saber, T., Taylor, C., O’Sullivan, J., et al. (2010). Angiogenesis and blood vessel stability in inflammatory arthritis. Arthritis Rheum. 62, 711-721. doi: 10.1002/art.27287

Khan, O. F., and Sefton, M. V. (2011). Endothelial cell behaviour within a microfluidic mimic of the flow channels of a modular tissue engineered construct. Biomed. Microdevices 13, 69-87. doi: 10.1007/s10544-010-9472-8

Knoerzer, D. B., Donovan, M. G., Schwartz, B. D., and Mengle-Gaw, L. J. (1997). Clinical and histological assessment of collagen-induced arthritis progression in the diabetes-resistant BB/Wor rat. Toxicol Pathol. 25, 13-19. doi: 10.1177/ 019262339702500103

Kragstrup, T. W., Jalilian, B., Hvid, M., Kjærgaard, A., Østgård, R., SchiøttzChristensen, B., et al. (2014). Decreased plasma levels of soluble CD18 link leukocyte infiltration with disease activity in spondyloarthritis. Arthritis Res. Ther. 16:R42.

Kuijpers, T. W., Van Lier, R. A. W., Hamann, D., De Boer, M., Thung, L. Y., Weening, R. S., et al. (1997). Leukocyte adhesion deficiency type 1 (LAD-1)/variant. A novel immunodeficiency syndrome characterized by dysfunctional $\beta 2$ integrins. J. Clin. Invest. 100, 1725-1733. doi: 10.1172/ jci119697

LaBranche, T. P., Hickman-Brecks, C. L., Meyer, D. M., Storer, C. E., Jesson, M. I., Shevlin, K. M., et al. (2010). Characterization of the KRN cell transfer model of rheumatoid arthritis (KRN-CTM), a chronic yet synchronized version of the K/BxN mouse. Am. J. Pathol. 177, 1388-1396. doi: 10.2353/ajpath.2010. 100195

Lally, F., Smith, E., Filer, A., Stone, M. A., Shaw, J. S., Nash, G. B., et al. (2005). A novel mechanism of neutrophil recruitment in a coculture model of the rheumatoid synovium. Arthritis Rheum. 52, 3460-3469. doi: 10.1002/ art. 21394

Lewis, M. J., Barnes, M. R., Blighe, K., Goldmann, K., Rana, S., Hackney, J. A., et al. (2019). Molecular portraits of early rheumatoid arthritis identify clinical and treatment response phenotypes. Cell Rep. 28, 2455.e-2470.e5.

Ley, K., Laudanna, C., Cybulsky, M. I., and Nourshargh, S. (2007). Getting to the site of inflammation: the leukocyte adhesion cascade updated. Nat. Rev. Immunol. 7, 678-689. doi: 10.1038/nri2156

Lim, E., Modi, K. D., and Kim, J. B. (2009). In vivo bioluminescent imaging of mammary tumors using IVIS spectrum. J. Vis. Exp. 26:1210.
Lioté, F., Boval-Boizardy, B., Weillz, D., Kuntz, D., and Wautieryz, J.-L. (1996). Blood monocyte activation in rheumatoid arthritis: increased monocyte adhesiveness, integrin expression, and cytokine release. Clin. Exp. Immunol. 106, 13-19. doi: 10.1046/j.1365-2249.1996.d01-820.x

Lliso-Ribera, G., Humby, F., Lewis, M., Nerviani, A., Mauro, D., Rivellese, F., et al. (2019). Synovial tissue signatures enhance clinical classification and prognostic/treatment response algorithms in early inflammatory arthritis and predict requirement for subsequent biological therapy: results from the pathobiology of early arthritis cohort (PEAC). Ann. Rheum. Dis. 78, 1642-1652. doi: 10.1136/annrheumdis-2019-215751

Ma, H. P., Deng, X., Chen, D. Y., Zhu, D., Tong, J. L., Zhao, T., et al. (2018). A microfluidic chip-based co-culture of fibroblast-like synoviocytes with osteoblasts and osteoclasts to test bone erosion and drug evaluation. R. Soc. Open Sci. 5:180528. doi: 10.1098/rsos.180528

Manasson, J., Blank, R. B., and Scher, J. U. (2020). The microbiome in rheumatology: where are we and where should we go? Ann. Rheum. Dis. 79, S727-S733.

Marcus, C., Thakur, M. L., Huynh, T. V., Louie, J. S., Leibling, M., Minami, C., et al. (1994). Imaging rheumatic joint diseases with anti-T lymphocyte antibody OKT-3. Nucl. Med. Commun. 15, 824-830. doi: 10.1097/00006231-19941000000008

Matsui, T., Akahoshi, T., Namai, R., Hashimoto, A., Kurihara, Y., Rana, M., et al. (2001). Selective recruitment of CCR6-expressing cells by increased production of MIP-3 $\alpha$ in rheumatoid arthritis. Clin. Exp. Immunol. 125, 155-161. doi: 10.1046/j.1365-2249.2001.01542.x

McGettrick, H. M., Butler, L. M., Buckley, C. D., Rainger, G., and Nash, G. B. (eds) (2012). Tissue stroma as a regulator of leukocyte recruitment in inflammation. J. Leukoc. Biol. 91, 385-400. doi: 10.1189/jlb.0911458

McGettrick, H. M., Hunter, K., Moss, P. A., Buckley, C. D., Rainger, G. E., and Nash, G. B. (2008). Direct observations of the kinetics of migrating T cells suggest active retention by endothelial cells with continual bidirectional migration. J. Leukoc. Biol. 85, 98-107. doi: 10.1189/jlb.0508301

McGettrick, H. M., Smith, E., Filer, A., Kissane, S., Salmon, M., Buckley, C. D., et al. (2009). Fibroblasts from different sites may promote or inhibit recruitment of flowing lymphocytes by endothelial cells. Eur. J. Immunol. 39, 113-125. doi: 10.1002/eji.200838232

Mcgettrick, H. M., Ward, L. S. C., Rainger, G. E., and Nash, G. B. (2017). Mesenchymal stromal cells as active regulators of lymphocyte recruitment to blood vascular endothelial cells. Methods Mol. Biol. 1591, 121-142. doi: 10. 1007/978-1-4939-6931-9_9

McNaughton, E. F., Eustace, A. D., King, S., Sessions, R. B., Kay, A., Farris, M., et al. (2018). Novel anti-inflammatory peptides based on chemokineglycosaminoglycan interactions reduce leukocyte migration and disease severity in a model of rheumatoid arthritis. J. Immunol. 200, 3201-3217. doi: 10.4049/ jimmunol.1701187

Meghezi, S., Seifu, D. G., Bono, N., Unsworth, L., Mequanint, K., and Mantovani, D. (2015). Engineering 3D cellularized collagen gels for vascular tissue regeneration. J. Vis. Exp. 100:e52812,

Menon, M., Benechet, A. P., and Khanna, K. M. (2017). Visualizing endogenous effector T cell egress from the lymph nodes. Methods Mol. Biol. 1591, 59-71. doi: 10.1007/978-1-4939-6931-9_5

Mertens, A. V., de Clerck, L. S., Moens, M. M., Bridts, C. H., and Stevens, W. J. (1994). Lymphocyte activation status, expression of adhesion molecules and adhesion to human endothelium in rheumatoid arthritis - relationship to disease activity. Res. Immunol. 145, 101-108. doi: 10.1016/s0923-2494(94) 80020-0

Mitchell, T. S., Moots, R. J., and Wright, H. L. (2017). Janus kinase inhibitors prevent migration of rheumatoid arthritis neutrophils towards interleukin8 , but do not inhibit priming of the respiratory burst or reactive oxygen species production. Clin. Exp. Immunol. 189, 250-258. doi: 10.1111/cei. 12970

Miyagawa, I., and Tanaka, Y. (2020). The approach to precision medicine for the treatment of psoriatic arthritis. Immunol. Med. 43, 98-102. doi: 10.1080/ 25785826.2020.1753430

Momcilovic, M., Bailey, S. T., Lee, J. T., Zamilpa, C., Jones, A., Abdelhady, G., et al. (2018). Utilizing18F-FDG PET/CT imaging and quantitative histology to measure dynamic changes in the glucose metabolism in mouse models of lung cancer. J. Vis. Exp. 137:57167. 
Morton, A. M., Sefik, E., Upadhyay, R., Weissleder, R., Benoist, C., and Mathis, D. (2014). Endoscopic photoconversion reveals unexpectedly broad leukocyte trafficking to and from the gut. Proc. Natl. Acad. Sci. U. S. A. 111, 6696-6701. doi: $10.1073 /$ pnas.1405634111

Muirden, K. D., and Mills, K. W. (1971). Do lymphocytes protect the rheumatoid joint? Br. Med. J. 4, 219-221. doi: 10.1136/bmj.4.5781.219

Muirden, K. D., and Senator, G. B. (1968). Iron in the synovial membrane in rheumatoid arthritis and other joint diseases. Ann. Rheum. Dis. 27, 38-48. doi: 10.1136/ard.27.1.38

Munir, H., Rainger, G., Nash, G. B., and McGettrick, H. (eds) (2015). Analyzing the effects of stromal cells on the recruitment of leukocytes from flow. J. Vis. Exp. 95:e52480.

Nakajima, A., Seroogy, C. M., Sandora, M. R., Tarner, I. H., Costa, G. L., TaylorEdwards, C., et al. (2001). Antigen-specific T cell-mediated gene therapy in collagen-induced arthritis. J. Clin. Invest. 107, 1293-1301. doi: 10.1172/jci12037

Nerviani, A., Di Cicco, M., Mahto, A., Lliso-Ribera, G., Rivellese, F., Thorborn, G., et al. (2020). A pauci-immune synovial pathotype predicts inadequate response to $\mathrm{TNF} \alpha$-Blockade in rheumatoid arthritis patients. Front. Immunol. 11:845. doi: 10.3389/fimmu.2020.00845

Neumüller, J., Dunky, A., Burtscher, H., Jilch, R., and Menzel, J. E. (2001). Interaction of monocytes from patients with psoriatic arthritis with cultured microvascular endothelial cells. Clin. Immunol. 98, 143-152. doi: 10.1006/clim. 2000.4953

Notni, J., Gassert, F. T., Steiger, K., Sommer, P., Weichert, W., Rummeny, E. J., et al. (2019). In vivo imaging of early stages of rheumatoid arthritis by $\alpha 5 \beta 1$-integrintargeted positron emission tomography. EJNMMI Res. 9:87,

Paleolog, E. M., Hunt, M., Elliott, M. J., Feldmann, M., Maini, R. N., and Woody, J. N. (1996). Deactivation of vascular endothelium by monoclonal anti-tumor necrosis factor $\alpha$ antibody in rheumatoid arthritis. Arthritis Rheum. 39, 10821091. doi: 10.1002/art.1780390703

Palframan, R., Airey, M., Moore, A., Vugler, A., and Nesbitt, A. (2009). Use of biofluorescence imaging to compare the distribution of certolizumab pegol, adalimumab, and infliximab in the inflamed paws of mice with collageninduced arthritis. J. Immunol. Methods 348, 36-41. doi: 10.1016/j.jim.2009. 06.009

Parsonage, G., Filer, A. D., Haworth, O., Nash, G. B., Rainger, G. E., Salmon, M., et al. (2005). A stromal address code defined by fibroblasts. Trends in Immunol. 26, 150-156. doi: 10.1016/j.it.2004.11.014

Pitzalis, C., Kelly, S., and Humby, F. (2013). New learnings on the pathophysiology of RA from synovial biopsies. Curr. Opin. Rheumatol. 25, 334-344. doi: 10. 1097/bor.0b013e32835fd8eb

Porter, C., Ennamorati, M., and Jain, N. (2018). In vivo photolabeling of cells in the colon to assess migratory potential of hematopoietic cells in neonatal mice. J. Vis. Exp. 138:57929.

Pucino, V., Certo, M., Bombardieri, M., Pitzalis, C., and Correspondence, C. M. (2019). Lactate buildup at the site of chronic inflammation promotes disease by inducing CD4\&\#x002B; T cell metabolic rewiring. Cell. Metab. 30, 10551074.e8.

Pucino, V., Certo, M., Varricchi, G., Marone, G., Ursini, F., Rossi, F. W., et al. (2020). Metabolic checkpoints in rheumatoid arthritis. Front. Physiol. 11:347. doi: 10.3389/fphys.2020.00347

Rainger, G. E., Stone, P., Morland, C. M., and Nash, G. B. (2001). A novel system for investigating the ability of smooth muscle cells and fibroblasts to regulate adhesion of flowing leukocytes to endothelial cells. J. Immunol. Methods. 255, 73-82. doi: 10.1016/s0022-1759(01)00427-6

Rothbauer, M., Höll, G., Eilenberger, C., Kratz, S. R. A., Farooq, B., Schuller, P., et al. (2020). Monitoring tissue-level remodelling during inflammatory arthritis using a three-dimensional synovium-on-a-chip with non-invasive light scattering biosensing. Lab Chip 20, 1461-1471. doi: 10.1039/c9lc01097a

Sackmann, E. K., Berthier, E., Young, E. W. K., Shelef, M. A., Wernimont, S. A., Huttenlocher, A., et al. (2012). Microfluidic kit-on-a-lid: a versatile platform for neutrophil chemotaxis assays. Blood 120:e45-e53,

Salmi, M., Rajala, P., and Jalkanen, S. (1997). Homing of mucosal leukocytes to joints: distinct endothelial ligands in synovium mediate leukocyte-subtype specific adhesion. J. Clin. Invest. 99, 2165-2172. doi: 10.1172/jci119389

Shen, Y., Wen, Z., Li, Y., Matteson, E. L., Hong, J., Goronzy, J. J., et al. (2017). Metabolic control of the scaffold protein TKS5 in tissue-invasive, proinflammatory T cells. Nat. Immunol. 18, 1025-1034. doi: 10.1038/ni. 3808

Shimaoka, Y., Attrep, J. F., Hirano, T., Ishihara, K., Suzuki, R., Toyosaki, T., et al. (1998). Nurse-like cells from bone marrow and synovium of patients with rheumatoid arthritis promote survival and enhance function of human B cells. J. Clin. Invest. 102, 606-618. doi: 10.1172/jci3162

Shu, Q., Amin, M. A., Ruth, J. H., Campbell, P. L., and Koch, A. E. (2012). Suppression of endothelial cell activity by inhibition of TNF $\alpha$. Arthritis Res. Ther. 14:R88.

Smith, E., McGettrick, H. M., Stone, M. A., Shaw, J. S., Middleton, J., Nash, G. B., et al. (2008). Duffy antigen receptor for chemokines and CXCL5 are essential for the recruitment of neutrophils in a multicellular model of rheumatoid arthritis synovium. Arthritis Rheum. 58, 1968-1973. doi: 10.1002/art.23545

Stamper, H. B., and Woodruff, J. J. (1976). Lymphocyte homing into lymph nodes: In vitro demonstration of the selective affinity of recirculating lymphocytes for high-endothelial venules*. J. Exp. Med. 144, 828-833. doi: 10.1084/jem.144. 3.828

Steele, M. M., Churchill, M. J., Breazeale, A. P., Lane, R. S., Nelson, N. A., and Lund, A. W. (2019). Quantifying leukocyte egress via lymphatic vessels from murine skin and tumors. J. Vis. Exp. 143:e58704.

Sudoł-Szopińska, I., Kontny, E., Maśliński, W., Prochorec-Sobieszek, M., Warczyńska, A., and Kwiatkowska, B. (2013). Significance of bone marrow edema in pathogenesis of rheumatoid arthritis. Pol. J. Radiol. 78, 57-63. doi: $10.12659 /$ pjr.883768

Szántó, S., Gál, I., Gonda, A., Glant, T. T., and Mikecz, K. (2004). Expression of L-selectin, but not CD44, is required for early neutrophil extravasation in antigen-induced arthritis. J. Immunol. 172, 6723-6734. doi: 10.4049/jimmunol. 172.11.6723

Tajik, N., Frech, M., Schulz, O., Schälter, F., Lucas, S., Azizov, V., et al. (2020). Targeting zonulin and intestinal epithelial barrier function to prevent onset of arthritis. Nat. Commun. 11:1995.

Tak, P. P., Taylor, P. C., Breedveld, F. C., Smeets, T. J. M., Daha, M. R., Kluin, P. M., et al. (1996). Decrease in cellularity and expression of adhesion molecules by anti- tumor necrosis factor $\alpha$ monoclonal antibody treatment in patients with rheumatoid arthritis. Arthritis Rheum. 39, 1077-1081. doi: 10.1002/art. 1780390702

Tanaka, Y., McInnes, I. B., Taylor, P. C., Byers, N. L., Chen, L., de Bono, S., et al. (2018). Characterization and changes of lymphocyte subsets in baricitinibtreated patients with rheumatoid arthritis: an integrated analysis. Arthritis Rheumatol. 70, 1923-1932. doi: 10.1002/art.40680

Taylor, P. C., Michael Peters, A., Paleolog, E., Chapman, P. T., Elliott, M. J., McCloskey, R., et al. (2000). Reduction of chemokine levels and leukocyte traffic to joints by tumor necrosis factor $\alpha$ blockade in patients with rheumatoid arthritis. Arthritis Rheum. 43, 38-47. doi: 10.1002/1529-0131(200001)43:1<38:: aid-anr6>3.0.co;2-1

Thurlings, R. M., Wijbrandts, C. A., Bennink, R. J., Dohmen, S. E., Voermans, C., Wouters, D., et al. (2009). Monocyte scintigraphy in rheumatoid arthritis: the dynamics of monocyte migration in immune-mediated inflammatory disease. PLoS One 4:e7865. doi: 10.1371/journal.pone.0007865

Traylor-Knowles, N. (2018). In situ hybridization techniques for paraffinembedded adult coral samples. J. Vis. Exp. 138:57853.

Tucker, D. K., Foley, J. F., Hayes-Bouknight, S. A., and Fenton, S. E. (2016). Preparation of high-quality hematoxylin and eosin-stained sections from rodent mammary gland whole mounts for histopathologic review. Toxicol. Pathol. 44, 1059-1064. doi: 10.1177/0192623316660769

Uno, K., Matsui, N., Nohira, K., Suguro, T., Kitakata, Y., Uchiyama, G., et al. (1986) Indium-111 leukocyte imaging in patients with rheumatoid arthritis. J. Nucl. Med. 27, 339-344.

Uno, K., Suguro, T., Nohira, K., Moriya, H., Saegusa, K., Anzai, Y., et al. (1992). Comparison of Indium-111-labeled leukocyte scintigraphy and Technetium$99 \mathrm{~m}$ joint scintigraphy in rheumatoid arthritis and osteoarthritis. Ann. Nucl. Med. 6, 247-251. doi: 10.1007/bf03164662

Van Den Berg, A., Mummery, C. L., Passier, R., and Van der Meer, A. D. (2019). Personalised organs-on-chips: functional testing for precision medicine. $L a b$ Chip 19, 198-205. doi: 10.1039/c8lc00827b

Veale, D., Yanni, G., Rogers, S., Barnes, L., Bresnihan, B., and Fitzgerald, O. (1993). Reduced synovial membrane macrophage numbers, elam-1 expression, and 
lining layer hyperplasia in psoriatic arthritis as compared with rheumatoid arthritis. Arthritis Rheum. 36, 893-900. doi: 10.1002/art.1780360705

Veihelmann, A., Harris, A. G., Krombach, F., Schütze, E., Refior, H. J., and Messmer, K. (1999). In vivo assessment of synovial microcirculation and leukocyte-endothelial cell interaction in mouse antigen-induced arthritis. Microcirculation 6, 281-290. doi: 10.1080/713773963

Venugopal Menon, N., Tay, H. M., Pang, K. T., Dalan, R., Wong, S. C., Wang, X., et al. (2018). A tunable microfluidic 3D stenosis model to study leukocyteendothelial interactions in atherosclerosis. APL Bioeng 2:016103. doi: 10.1063/ 1.4993762

Verschure, P. J., Noorden, C. J. F., and Dijkstra, C. D. (1989). Macrophages and dendritic cells during the early stages of antigen-induced arthritis in rats: immunohistochemical analysis of cryostat sections of the whole knee joint. Scand. J. Immunol. 29, 371-381. doi: 10.1111/j.1365-3083.1989.tb01136.x

Vestweber, D. (2015). How leukocytes cross the vascular endothelium. Nat. Rev. Immunol. 15, 692-704. doi: 10.1038/nri3908

Wagner, U. G., Kurtin, P. J., Wahner, A., Brackertz, M., Berry, D. J., Goronzy, J. J., et al. (1998). The role of CD8+ CD40L+ T cells in the formation of germinal centers in rheumatoid synovitis. J. Immunol. 161, 6390-6397.

Wang, C. R., Liu, M. F., Huang, Y. H., and Chen, H. C. (2004). Up-regulation of XCR1 expression in rheumatoid joints. Rheumatology 43, 569-573. doi: 10.1093/rheumatology/keh147

Wei, K., Korsunsky, I., Marshall, J. L., Gao, A., Watts, G. F. M., Major, T., et al. (2020). Notch signalling drives synovial fibroblast identity and arthritis pathology. Nature 582, 259-264. doi: 10.1038/s41586-020-2222-z

Weyand, C. M., Wu, B., and Goronzy, J. J. (2020). The metabolic signature of T cells in rheumatoid arthritis. Curr. Opin. Rheumatol. 32, 159-167. doi: 10.1097/bor. 0000000000000683

White, A. G., Maiello, P., Coleman, M. T., Tomko, J. A., Frye, L. J., Scanga, C. A., et al. (2017). Analysis of 18FDG PET/CT imaging as a tool for studying Mycobacterium tuberculosis infection and treatment in non-human primates. J. Vis. Exp. 127:56375.

Williams, R. O., Feldmann, M., and Maini, R. N. (1992). Anti-tumor necrosis factor ameliorates joint disease in murine collagen-induced arthritis. Proc. Natl. Acad. Sci. U. S. A. 89, 9784-9788. doi: 10.1073/pnas.89.20.9784

Wörsdörfer, P., Dalda, N., Kern, A., Krüger, S., Wagner, N., Kwok, C. K., et al. (2019). Generation of complex human organoid models including vascular networks by incorporation of mesodermal progenitor cells. Sci. Rep. 9:15663,

Wu, X., Newbold, M. A., Gao, Z., and Haynes, C. L. (2017). A versatile microfluidic platform for the study of cellular interactions between endothelial cells and neutrophils. Biochim. Biophys. Acta Gen. Subj. 1861, 1122-1130. doi: 10.1016/ j.bbagen.2017.02.012

Xu, H., Zhao, H., Fan, D., Liu, M., Cao, J., Xia, Y., et al. (2020). Interactions between gut microbiota and immunomodulatory cells in rheumatoid arthritis. Mediators Inflamm. 2020:1430605.

Yokota, A., Murata, N., Saiki, O., Shimizu, M., Springer, T. A., and Kishimoto, T. (1995). High avidity state of leukocyte function-associated antigen-1 on rheumatoid synovial fluid T lymphocytes. J. Immunol. 155, 4118-4124.

Youssef, P. P., Cormack, J., Evill, C. A., Peter, D. T., Roberts-Thomson, P. J., Ahern, M. J., et al. (1996). Neutrophil trafficking into inflamed joints in patients with rheumatoid arthritis, and the effects of methylprednisolone. Arthritis Rheum. 39, 216-225. doi: 10.1002/art.1780390207

Zhang, J., Alcaide, P., Liu, L., Sun, J., He, A., Luscinskas, F. W., et al. (2011). Regulation of endothelial cell adhesion molecule expression by mast cells, macrophages, and neutrophils. PLoS One 6:e14525. doi: 10.1371/journal.pone. 0014525

Zhang, X., Nakajima, T., Goronzy, J. J., and Weyand, C. M. (2005). Tissue trafficking patterns of effector memory $\mathrm{CD} 4+\mathrm{T}$ cells in rheumatoid arthritis. Arthritis Rheum. 52, 3839-3849. doi: 10.1002/art.21482

Conflict of Interest: JM’s Ph.D. studentship was partially funded by Novartis.

The remaining authors declare that the research was conducted in the absence of any commercial or financial relationships that could be construed as a potential conflict of interest.

Copyright (๑) 2021 Manning, Lewis, Marsh and McGettrick. This is an open-access article distributed under the terms of the Creative Commons Attribution License (CC BY). The use, distribution or reproduction in other forums is permitted, provided the original author(s) and the copyright owner(s) are credited and that the original publication in this journal is cited, in accordance with accepted academic practice. No use, distribution or reproduction is permitted which does not comply with these terms. 